\title{
The Good, The Bad, and The Puzzled: Coercion and Compliance
}

\author{
Lucas Miotto*
}

\begin{abstract}
The assumption that coercion is largely responsible for our legal systems' efficacy is a common one. I argue that this assumption is false. But I do so indirectly, by objecting to a thesis I call "(Compliance)", which holds that most citizens comply with most legal mandates most of the time at least partly in virtue of being motivated by legal systems' threats of sanctions and other unwelcome consequences. The relationship between (Compliance) and the efficacy of legal systems is explained in section 1. There I also show that (Compliance) must be rejected for it relies on unsubstantiated empirical assumptions. In section 2, I claim that an alternative, and more refined, formulation of (Compliance) also lacks adequate support. I conclude with a few general remarks about the centrality of coercion in our thought and talk about legal systems.
\end{abstract}

Keywords: Coercion, Compliance, Obedience, Efficacy, Practical Difference, General Jurisprudence.

\section{Introduction}

'When mores are sufficient, laws are unnecessary. When mores are insufficient, laws are unenforceable'.

The assumption that coercion is largely responsible for our legal systems' efficacy is a common one. Legal and political philosophers have claimed that 'law needs to be coercive, ${ }^{2}$ or that '[w]ithout coercion (...) law would be unable to succeed in being practiced within a community, ${ }^{3}$ or even that '[n]o [human] society can subsist without government and coercion, and consequently without laws to control and restrain men's lusts and their unbridled urges. ${ }^{4}$

I argue that this assumption is false. But I do so indirectly, by challenging the following thesis:

(Compliance): in typical legal systems, ${ }^{5}$ most citizens comply with most legal mandates most of the time at least partly in virtue of being motivated by legal systems' threats of sanctions and other unwelcome consequences.

The relationship between (Compliance) and the efficacy of legal systems is explained in section 1. There I also argue that (Compliance) must be rejected for it relies on unsubstantiated empirical assumptions. In section 2 I claim that an alternative, and more refined, formulation of (Compliance) also lacks adequate support. I conclude with a few general remarks about the place of coercion in our thought and talk about legal systems.

\footnotetext{
Assistant Professor of Legal Philosophy at University of Maastricht. Contact: lucas.miottolopes@maastrichtuniversity.nl. For comments and suggestions that greatly improved this paper I'm thankful to Anthony Duff, Himani Bhakuni, James Edwards, Luís Duarte d'Almeida, Neil Walker, and the editors of this book.

${ }^{1}$ This quote is often attributed to Durkheim, though it is never found in one of his books.

2 Finnis (2011), p. 266.

${ }^{3}$ Lamond (2001), p. 45.

${ }^{4}$ Spinoza (2007), secs 63-64.

${ }^{5}$ Throughout the paper I take "typical legal systems" to refer to those legal systems that currently exist in western democratic states and those that closely resemble them.
} 


\section{The Tale of the Bad Man}

The claim that legal systems are efficacious can mean different things. Usually, however, legal philosophers hold that a legal system is efficacious only if a sufficient number of citizens-i.e., the addressees of legal mandates - comply with a sufficient number of legal mandates. ${ }^{6}$ Under this description, the relationship between compliance and the efficacy of legal system is straightforward: compliance is a necessary condition of the efficacy of legal systems. For the purposes of the present discussion, I'll assume that this relationship holds and ignore a few complications about it. ${ }^{7}$

To say that citizens comply with a given legal mandate doesn't presuppose that citizens comply for any particular reason. Compliance is a thin notion; it can be achieved by any reason whatsoever; even by luck. But many-from Hobbes to public choice economists to contemporary legal and political philosophers-depict human beings as somewhat akin to Holmes's famous character, the bad man: someone who is primarily disposed to maximise self-interest and who is willing to flout the law whenever he can benefit from doing so. ${ }^{8}$ They think that in a world like ours, a large and stable level of compliance can only be achieved by the coercive force of law. Without coercion-and by "coercion" it is meant nothing more than the threat of sanctions or other unwelcome consequences - compliance and cooperation would give in to anarchy and self-interest. Without coercion, therefore, our legal systems would cease to be efficacious.

Most actual legal systems are indeed efficacious. If it is true that a legal system in a world like ours wouldn't be efficacious but for coercion, then it must be true that coercion does motivate many, if not most, citizens to comply with most legal mandates in actual legal systems. So, for the claim that coercion is largely responsible for the efficacy of our legal systems to run, (Compliance) must also run.

(Compliance) seems to have some intuitive appeal. But its truth, as well as the accuracy of using the bad man as a description of the typical human character, hang on empirical considerations. One cannot assume these claims without checking the relevant empirical facts. That is what I'm going to do next.

\footnotetext{
${ }^{6}$ See, Burazin (2019).

${ }^{7}$ I'll ignore complications associated with the relevant number of citizens that must comply with legal mandates and complications associated with the relevant number of legal mandates that must be complied with. I'll equally ignore the discussion about whether mandates of a certain type must be complied by a certain type of citizen for a legal system to be efficacious. As important as these discussions may be for a rigorous understanding of the efficacy of legal systems, there is no need to engage with them for the purposes of this paper.

${ }^{8}$ A number of legal philosophers have adopted a somewhat pessimistic view of human character and dispositions. For some recent examples of this presupposition in legal philosophy see, Plaxton (2012); Himma (2016). A similar presupposition is also widespread in political philosophy and economics. Elisabeth Anderson provides numerous examples in Anderson (2000). See also Brennan (2017).
} 


\subsection{The Search for the Bad}

The empirical literature on deterrence provides a good starting point. Many studies have examined the extent to which the threat of legal sanctions deter breaches. The findings - especially those about the impact of criminal sanctions on citizens' behaviour-are interesting. Empirical studies show that deterrence is much less successful than often assumed. ${ }^{9}$ Different factors contribute to that. For example, behavioural studies have found that deterrence sometimes fails in virtue of knowledge about criminal laws (i.e., knowledge of which conduct are criminalised, which actions are required, what excuses are available, what sanctions are applied, and of their magnitude) being weak among citizens; even among those who would benefit the most from knowing what the law requires. ${ }^{10}$ The formulation of actual legal rules seems to have no impact on citizens' beliefs about what legal rules require. ${ }^{11}$ Changes in the formulation of legal rules are often neither accompanied by a corresponding change in citizens' beliefs about what the rules require nor by a change in behaviour.

These findings about citizens' knowledge, however, cannot by themselves explain why deterrence is weak. Certainly, they do show that the way legal rules are formulated doesn't directly impact citizens' behaviour and that sometimes citizens have no idea of what legal systems require. That may explain why some criminal rules (e.g., those largely unknown to citizens) don't deter or affect citizens' motivation in any way. But the point cannot be generalised. Requiring that, to be deterred, citizens must know the exact conduct which is criminalised or the sanctions that may be applied in case of a breach would be too demanding. Citizens need not know exactly which sanctions are applicable or the exact formulation of a legal rule in order to be deterred. Having a rough belief about what is criminalised and a belief that authorities are likely to do something unwelcome to those who engage in certain behaviours may suffice for deterrence. In fact, some studies corroborate this. They suggest that citizens believing both that authorities are likely to enforce sanctions and that unlawful behaviour is likely to be detected suffice to deter some breaches. ${ }^{12}$

There are, however, more factors which corroborate the view that deterrence is an overrated explanation for citizens' compliance with legal rules. Studies focused on criminal laws found that citizens 'commonly assume the law to be as they think it should be, so they assume the existence of criminal law rules that correspond to their own intuitions about justice' and act accordingly. ${ }^{13}$ Reinforcing this last point, independent studies have found that moral beliefs (what social scientists often call 'personal morality') largely influence citizens' compliance with legal mandates. ${ }^{14}$ Most citizens most of the time seem to comply with legal mandates simply because what

\footnotetext{
${ }^{9}$ See, e.g., Tyler (2006a), p. 67. Robinson and Darley have reviewed the relevant literature and provided a number of helpful references on this point. See Robinson and Darley (2004).

${ }^{10}$ Robinson and Darley (2004), sec. 1A and passim.

${ }^{11}$ Sometimes this generates pernicious effects. For example, it has been shown that because of the lack of relevant legal knowledge, workers tend to enter employment contracts on the assumption that legal rules extend to them far greater protection against unfair employment contracts than they actually do. See Kim (1997).

${ }^{12}$ See, e.g., Paternoster (2010). For what is worth, even Robinson and Darley admit that. Robinson and Darley (2004), p. 173.

${ }^{13}$ Robinson and Darley (2004), pp. 176-177 my emphasis. See also, Darley et al. (2001); Darley et al. (1996).

${ }^{14}$ Tyler (2006a), pp. 67-68.
} 
legal mandates require corresponds to what citizens independently or collectively take to be the right thing to do. The fact that legal rules demand a particular behaviour and apply sanctions to deviations and the very fact that a legal rule requiring a given behaviour exists is usually irrelevant to citizens: legal mandates frequently don't number among the considerations citizens take into account when deciding what to do. ${ }^{15}$

Furthermore, empirical studies suggest that even when people do know what legal mandates require and the sanctions legal systems threaten, citizens still tend not to be motivated by them. This is because what legal mandates require clashes with what citizens think is fair, ${ }^{16}$ or because the way legal regulation and enforcement are designed make non-compliance appealing, ${ }^{17}$ or even, sometimes, because citizens are unable (e.g., in virtue of psychological problems) or unwilling (e.g., in virtue of the benefits of breaching the law, or in virtue of a strong desire to satisfy personal vendetta) to bring this knowledge to bear on their actions. ${ }^{18}$

Moreover, some studies show that sometimes intensifying the strength of sanctions or the ratio of enforcement may even increase non-compliance instead of decreasing it. ${ }^{19}$ In certain contexts, sanctions can backfire: they end up promoting the behaviours they were supposed to deter. Instead of being taken as a disincentive and deterring behaviour, they are taken as a price worth paying to perform a particular action, or even lead to the development of harmful social norms. ${ }^{20}$ The Prohibition in the 1920's United States is a telling example.

These findings aren't — and shouldn't be-surprising. Legal rules don't take place in a 'social vacuum'; ${ }^{21}$ they very often regulate behaviour which already possesses social significance, and which is heavily influenced by citizens' cultural, social, and moral norms and beliefs. And given the strength of these factors, often the best strategy for legal systems is, as far as possible, to work in tandem with them. That seems to be what typical legal systems attempt to do most of the time.

What is surprising, however, is the extent to which legal and political philosophers tend to ignore these points and continue to accord legal coercion a central place in both the explanation of citizens' motivation to cooperate with each other and in the explanation of their motivation to comply with legal mandates. This tendency has even been described as a bias. ${ }^{22}$ Not only do many philosophers seem biased towards giving too much prominence to the role of legal sanctions in fostering compliance and cooperation, but also towards an overly pessimistic view about human character.

\footnotetext{
${ }^{15}$ See Darley et al. (2001); Nadler (2004); Tyler (2006a); Tyler (2006b); Schauer (2015), p. 59.

${ }^{16}$ Nadler (2004); Mullen and Nadler (2008); Robinson et al. (2010).

${ }^{17}$ Raymon Paternoster claims that even if we assume that agents are 'rational actors' (a la Holmes's bad man), there are reasons to think that the way actual criminal system is designed is insufficient to effectively change behaviour. See Paternoster (2010), sec. VI.

18 Robinson and Darley provide a helpful review of the empirical literature on this point. See Robinson and Darley (2004), pp. 178-182 and references therein.

${ }^{19}$ Sherman (1993).

20 Frey and Oberholzer-Gee (1997); Gneezy and Rustichini (2000); Fehr and Rockenbach (2003); Heyman and Ariely (2004); Abbink et al. (2017).

${ }^{21}$ Nadler (2017), p. 65.

22 Brennan (2017).
} 
Contrary to this pessimistic view on human character, a large bulk of evidence from political science, social and cognitive psychology, and economics suggest that a more apt model for human character is that of the good person: someone who is disposed to do what she believes is fair and in agreement with her cultural, social, and moral norms and beliefs, and to cooperate when she believes that others are likely to do so. ${ }^{23}$ Many studies have shown that, with some degree of variation across different cultures, humans have altruistic, prosocial, and cooperative dispositions and that cooperation tends to be favoured even when self-interest must be sacrificed. ${ }^{24}$

In addition, economists and social scientists have repeatedly emphasised that a large part of the social order we enjoy is not explained by the threat of legal sanctions or other unwelcome consequences. They have, time and again, pointed out how individuals and groups, by voluntarily cooperating and trusting each other, have collectively devised effective and ingenious solutions to a number of complex social and economic problems (ranging from the development of intricate systems of allocation and protection of property rights to systems of benefit-sharing and distribution of public goods) in the absence of the coercive sword of legal systems and the state. ${ }^{25}$ To insist that the social order and stability that most current legal systems enjoy is largely a product of legal coercion is to disseminate a mistaken view.

All suggests that neither (Compliance), nor the overly pessimistic view of human character that many legal and political philosophers assume are accurate views. Granted: constructs such as the bad man might still be valuable to other theoretical purposes. ${ }^{26}$ But in the face of current evidence, we have good reason to no longer tell the tale of the bad man when describing the usual human behaviour.

Of course, we cannot simply generalise and say that the threat of unwelcome consequences never motivates citizens to perform or to abstain from performing actions. There are many instances where the influence of the threat of unwelcome consequences on citizens' behaviour is well-documented. ${ }^{27}$ Sometimes, legal systems do issue legal mandates that challenge citizens' cultural, social, and moral norms and beliefs. When that happens, the possibility of legal systems doing something unwelcome to citizens tends to figure in their motivation to comply with legal mandates. On some occasions, it is not an exaggeration to say that citizens' beliefs in the likelihood of being sanctioned is the reason why they comply with legal mandates. There is a garden-variety of

\footnotetext{
${ }^{23}$ Notice that 'good person' here is not being used to suggest that people are generally morally good or virtuous. 'Good' is being used in the sense that people have a disposition to conditionally cooperate: to cooperate when they believe others will do the same. In that line, Samuel Bowles and Herbert Gintis, for example, calls humans the 'cooperative species'. Bowles and Gintis (2011).

24 The literature is quite extensive. Some helpful examples are Dawes et al. (1990); Batson and Shaw (1991); Anderson (2000); Bicchieri (2006), chap. 4; Bowles and Gintis (2011); Embrey et al. (Forthcoming); Burton-Chellew et al. (2017).

${ }^{25}$ Ostrom (1990); Ellickson (1991); Stringham (2015); Ellickson (2017); Brennan (2017).

${ }^{26}$ Economists have extensively relied on a similar model of behaviour: the homo economicus. As some suggest, the homo economicus was a useful construct that allowed economists to build economic and mathematical models in a time where economic tools were more rudimentary than they are nowadays. Some contemporary economists, however, urge for the abandonment of the construct given that now we have better tools to build economic models based on a less simplified assumption of human character and rationality. See Thaler (2000). On the importance of the homo economicus construct to economic theory, see Ross (2012).

${ }^{27}$ Frederick Schauer provides many helpful references. See Schauer (2015), chaps 5-6.
} 
examples. Examples ranging from the burkini ban to prohibitions on the use of recreational drugs, to laws requiring the use of helmets ${ }^{28}$ and the imposition of curfews come to mind.

Yet, as familiar and common as examples like these may seem to be, we should resist the temptation to take them as representative of what typical legal systems do to most citizens most of the time. Some legal mandates of typical legal systems are indeed complied primarily in virtue of the threat of legal sanctions (and for some citizens the bad man is certainly a more accurate model than the good person's). But, as far as our best empirical findings show, most legal mandates aren't. Even Frederick Schauer, a fierce advocate of the centrality of coercion to typical legal systems, has granted this point after examining the relevant empirical evidence. In his own words:

$[\mathrm{M}]$ ost people make decisions about what to do and what not to do based on some complex mix of reasons of preference, prudence, and morality, but it is a mix that need not include the law. For most people most of the time, much that they do is consistent with the law, but is not done because of the law. ${ }^{29}$

This remark, however, may strike some as odd. How is it possible for someone, like Frederick Schauer, to admit that legal coercion doesn't influence most citizens' behaviour most of the time and still accord coercion a central place in explaining the efficacy of legal systems? Something must have gone wrong somewhere. That is what I try to find out in the next section.

\section{Enter the Puzzled}

There is a tension in simultaneously claiming that coercion has a central place in the explanation of the efficacy of legal systems and that coercion doesn't figure in most citizens' motivation to comply with most legal mandates most of the time. At times, this tension seems to be present in Frederick Schauer's recent work on the coerciveness of legal systems. It is possible, however, to construe Schauer's views in a more charitable way; a way that resolves this tension.

One of Schauer's main goals in his recent work is to find out how legal systems make a practical difference in citizens' lives, i.e., how they 'pla[y] a role in determining the actions and decisions of its subjects'. ${ }^{30}$ One way to understand his broader project is to interpret it as an attempt to answer the following question: in virtue of what do legal systems influence citizens' behaviour? His general answer is that when legal systems make a practical difference in citizens' lives-i.e., when legal systems influence citizens' behaviour - they do so mainly in virtue of coercion.

We can interpret this answer in purely statistical terms. ${ }^{31}$ Schauer seems to be defending the view that in the vast majority of circumstances where legal systems influence behaviour, the influence is due to the threat of unwelcome consequences. He sympathises with the view that law's non-coercive influence 'is so small as to be hardly

\footnotetext{
${ }^{28}$ For a helpful analysis of how helmet laws clashed with the cultural values of some groups in the USA, see Jones and Bayer (2007).

${ }^{29}$ Schauer (2015), p. 50 my emphasis.

${ }^{30}$ Ibid., p. 54.

${ }^{31}$ Several passages in Schauer's recent book corroborate this view. See, for example, Ibid., p. 46.
} 
worth worrying about' ${ }^{32}$ All suggests that Schauer-and maybe others - has never really defended (Compliance). Instead he-and maybe others-has defended the following view:

(Compliance*) Most of the time typical legal systems influence citizens' behaviour, they do so via the threat of unwelcome consequences.

Schauer - and maybe others - is, therefore, not strictly concerned with the relationship between coercion and the efficacy of typical legal systems. Instead, he is interested in the relationship between coercion and typical legal systems' actual influence on behaviour.

While believing that this is Schauer's view, I'm not too concerned with whether this is really his view or not. It is a view that is interesting and worth discussing regardless. More to the point, we can see that (Compliance*) is resistant to the objection that I raised in the previous section: even if true that most citizens most of the time don't comply with legal mandates because of coercion, it could still be true that in most occasions legal systems do succeed in influencing citizens' behaviour, the influence is due to the threat of unwelcome consequences.

Does (Compliance*) hold? Schauer thinks it does and accuses those who think otherwise of making an empirical mistake. According to Schauer, some philosophers and sociologists have assumed that most citizens are exclusively 'law-motivated', i.e. that most citizens 'comply with the law just because it is the law'. 33

If most people are exclusively law-motivated-Schauer calls them 'puzzled people' - then it must be false that legal systems influence most citizens' behaviour via the threat of unwelcome consequences. ${ }^{34}$ Under the assumption that most citizens are puzzled people, it would follow that legal systems influence the behaviour of most citizens just by issuing legal mandates and letting citizens know the content of these mandates. Schauer, however, thinks that there are not as many puzzled people in the world as some philosophers and sociologists would have us believe. ${ }^{35}$

To some extent, Schauer's discussion of the puzzled person is itself puzzling. First, the way Schauer characterises the puzzled person makes us wonder what puzzles the puzzled person. If the puzzled person is generally motivated to comply with the law just because it is the law, it seems that she is not really puzzled about what to do. On the contrary, the puzzled person, as Schauer describes them, is more aptly described as a law-maniac; a devotee of the law who follows the law no-questions-asked. ${ }^{36}$ More importantly, that description of people's motivation raises some questions. For one, it

\footnotetext{
32 Ibid., p. 46. As I said, Schauer sympathises with this view. Schauer, however, never explicitly endorses it in such strong terms (though much of his book suggests that he does endorse this thesis in these terms). In the quoted passage, Schauer is talking about a view that someone may possibly hold (it is, by the way, a view explicitly endorsed by Michael Plaxton. See Plaxton (2012).

${ }^{33}$ Schauer (2015), p. 47.

${ }^{34}$ Ibid., pp. 47-48.

${ }^{35}$ See Ibid., chap. 5 and passim.

${ }^{36}$ Mark Greenberg has recently made a similar point. He thinks that Schauer's characterisation of the puzzled person is that of someone who has a fetish for the law. See Greenberg (2018), p. 376.
} 
raises the question of whether any philosopher or sociologist has really defended the view that most people follow the law just because it is the law.

Before answering that, let me first deal with a preliminary worry: it is not entirely clear what it is for someone to comply with the law just because it is the law. The phrase seems to suggest that the simple fact that legal systems require an action is taken by someone as the sole reason or motive to perform or abstain from performing it. If that is how we should understand it, then the view faces a problem.

Suppose Puzzly tells us that she follows the law most of the time just because it is the law. In this case, it seems that we could still ask Puzzly for further explanation. In particular, we could ask her to present us the reasons why she thinks being the law makes something merit compliance in the first place. There can be multiple answers here. Puzzly, for instance, may think that if something is the law it is the right thing to do, or is what other people will likely do, or is what her country expects her to do, or is in her best interest, and so forth. A simple 'I follow the law just because it is the law' may hide many different motivations, including motivations based on prudence and morality that Schauer didn't expect to find in those who 'follow the law just because it is the law'. If this is true, then perhaps this explains why Schauer didn't find many instances of people who comply with the law just because it is the law. ${ }^{37}$

Coming back to a previous point: have philosophers and sociologists really assumed that most people comply with the law just because it is the law? No. Schauer's criticism is mainly directed towards H.L.A Hart, ${ }^{38}$ from whom Schauer borrows the reference to the 'puzzled person'. Hart's characterisation of the puzzled person, however, is at odds with Schauer's in an important way. Here is the view Schauer attributes to Hart:

Hart's puzzled person is thus someone who follows the law just because it is the law even when what the law requires seems not only not in her best interest but also contrary to her best judgment. ${ }^{39}$

For Hart, however, the puzzled person is not someone who is exclusively lawmotivated. Instead, the puzzled — or 'ignorant' — person is just someone who is confused and looks at law for guidance. In Hart's own words, the 'puzzled man' or 'ignorant man' is someone 'who is willing to do what is required, if only he can be told what it is' ${ }^{40}$ This description is compatible with the puzzled person being someone who is willing to do what the law requires for a number of different reasons. The puzzled person can be a patriot who wants to know what the law is in order to honour her country, or a lazy-conformant who follows the law because it spares her some effort, or someone who believes that the laws of her jurisdiction are generally fair and merit obedience.

\footnotetext{
${ }^{37}$ I make a similar point in Miotto (2016), pp. 233-234. Mark Greenberg has also recently made a similar point and emphasises that the puzzled person can follow the law for moral reasons. See Greenberg (2018).

${ }^{38}$ Schauer (2015), pp. 46-48.

${ }^{39}$ Ibid., p. 62.

${ }^{40}$ Hart (2012), p. 40.
} 
The above is not just a charitable interpretation of what Hart has said about the puzzled person. It also aligns with Hart's broader view that actual people follow the law for a "variety of motives"41 and that legal systems still have a point in guiding and helping people's lives regardless of the reasons why they comply with the law.

The upshot is that, contrary to what Schauer suggests, Hart (but also others who Schauer criticises) ${ }^{42}$ has never assumed that most people are exclusively lawmotivated and thus cannot be blamed for making an empirical mistake about how legal systems influence behaviour.

Schauer's focus on the puzzled person is misguided for yet another reason. A reason that, even though obvious, is more fundamental to the present discussion. The reason is that, contrary to what Schauer seems to suggest, one need not defend the idea that most citizens fit Schauer's description of the puzzled person to refute (Compliance*). Requiring that-like Schauer does-is too demanding. Schauer may be right that most people in most legal systems don't comply with the law just because it is the law. But that just shows that most people aren't law-maniacs, which is hardly something anyone would dispute. To argue against (Compliance*), all one needs to establish is that most of the times legal systems influence citizens' behaviour they do so by ways other than the threat of sanctions or unwelcome consequences. In that regard, there are some empirical findings worth examining.

\subsection{Covenants without Swords}

It is widely recognised - at least by sociologists and social psychologists - that legal systems influence behaviour independently from the threat of unwelcome consequences. Sociologists often highlight the relationship between the belief that a legal system is legitimate and the likelihood of citizens complying with legal mandates. The point is not new; it can even be traced back to Max Weber, to whom legitimacy was a key factor to make legal (and social) orders more stable. ${ }^{43}$ A number of recent - or relatively recent - empirical studies have attempted to analyse the relationship between legitimacy and compliance in a more systematic way. For the purposes of empirical inquiry, sociologists and political scientists often presuppose a thin notion of legitimacy. They presuppose that a legal system is legitimate either when citizens believe they (morally) ought to obey the systems' mandates or when citizens express approval or allegiance to the system. ${ }^{44}$

Some studies found that legitimacy 'has a significant independent effect on compliance, even when other potential causal factors are controlled for ${ }^{45}$ and that the

\footnotetext{
41 "[S]ome [people obey the law] from prudential calculation that the sacrifices are worth the gains, some from a disinterested interest in the welfare of others, and some because they look upon the rules as worthy of respect in themselves and find their ideals in devotion to them.”. Ibid., p. 197.

${ }^{42}$ Tom Tyler is another example. Contrary to what Schauer suggests, Tyler doesn't assume that there is a vast number of puzzled people in our societies. Besides, in his empirical studies, Tyler distinguishes quite a few different motives for following the law (e.g., deterrence, legitimacy, peer disapproval, political factors, etc) and measures the influence of each of these distinct motives in isolation. Tyler also recognises that people often comply with the law for a mix of motives. See Tyler (2006a), p. 59.

${ }^{43}$ Weber (1978), pp. 31-33.

${ }^{44}$ Tom Tyler provides a helpful overview of the concept of legitimacy presupposed in empirical studies. See, Tyler (2006a), pp. 27-30.

${ }^{45}$ Ibid., p. 58.
} 
relationship between legitimacy and compliance is linear-i.e., 'as one increases so does the other' ${ }^{46}$ These studies on the influence of legitimacy on compliance, however, don't establish the exact proportion of citizens who are influenced by legal system's legitimacy (and not by the threat of unwelcome consequences). We cannot conclude, based on these studies alone, that most citizens are influenced by legal systems in virtue of legal mandates being legitimate. All we can say is that the number of citizens who are influenced by legal systems in this way is not insignificant.

There is, however, reason to believe that legal systems influence behaviour in ways other than legitimacy and coercion. In a number of occasions, people do what they think is morally right. But they don't do so just because that is what they would have done in the absence of legal systems' influence. Instead, people have-or take themselves to have - moral reasons to engage in some behaviours at least partly because these behaviours were required or permitted by a legal system. As the recent works of Robert Hughes and Mark Greenberg emphasise, legal systems influence behaviourand, to what is worth, make a practical difference-by influencing citizens' 'moral profile', i.e., citizens' moral beliefs, reasons, and positions (their duties, permissions, powers, and so forth). ${ }^{47}$

There are at least two ways legal systems affect citizens' moral profile. The first, and milder, way is that issuing a given law at times influences citizens' perception of the rightfulness or wrongfulness of an action, which leads citizens to alter their behaviour. ${ }^{48}$ Recent empirical studies corroborate this point. It has been found that legal systems influence people's moral beliefs and actions even when people are aware that sanctions won't be enforced. For example, Bert Huang's recent work has found that people tend to change their decisions in moral dilemmas when they believe that one of the options in the dilemma is favoured by the law (even when they know that there is no legal sanction for choosing the option proscribed by law). ${ }^{49}$

The second, and more robust, way legal systems affect citizens' moral landscape is by creating or altering citizens' moral reasons and positions. ${ }^{50}$ Property rights are an example. ${ }^{51}$ It is often said that most people refrain from theft for lawindependent reasons; that people would not steal from one another in the absence of legal rules. But this is misleading. It is plausible to think that at least some property rights that we enjoy in current societies partly exist in virtue of legal rules. If this is so, then - at least in some cases - a 'moral motive for refraining from theft is not a lawindependent motive'; ${ }^{52}$ its existence partly depends on the existence of a legal system and the property rules it creates.

\footnotetext{
${ }^{46}$ Ibid., p. 57. See also Gibson et al. (2005); Tyler (2006a); Papachristos et al. (2012); Tyler and Jackson (2014).

${ }^{47}$ Greenberg (2018), p. 377; Hughes (2018).

${ }^{48}$ This way is not mentioned by Mark Greenberg or Robert Hughes. However, it is consistent with the point they make.

${ }^{49}$ Huang (2017).

${ }^{50}$ Greenberg (2018), p. 377 and passim; Hughes (2018), pp. 362-364. The general point being made here is an old one. It can be traced back to Aquinas and his idea of determinatio: that legal systems can create moral reasons by making precise what morality leaves imprecise. See, Aquinas (1947), p. Q.95.

${ }^{51}$ Hughes (2018).

${ }^{52}$ Ibid., p. 364.
} 
The upshot is that some people who are taken, or who could be taken, and who I myself have taken in the first section of this paper to not be influenced by legal systems may in reality behave the way they behave partly in virtue of the (non-coercive) influence of legal systems. And that can be the case even when people are themselves not aware of the extent to which their actions and their moral beliefs, motives, and positions are influenced by legal systems. ${ }^{53}$

Determining which - if any - of the moral reasons are partly constituted by legal systems isn't an empirical issue. Whether, for example, some property rights are partly constituted by legal rules and, thus, whether citizens' moral reasons to respect property rights partly owe their existence to legal rules hang on a theory of property rights. It is not my job here to propose or defend such a theory. But it is not implausible - or at least not obviously implausible - to assume that examples where legal systems, as it were, shape citizens' moral reasons to comply with the law exist. (For instance, think of the moral reason to pay a specific amount of tax, or the reason to pay a specific amount of damages to a specific person, or the moral reason not to make noise of a particular magnitude at a particular hour, or the reason not to drive faster than a specific speed).

What is an empirical issue, however, is figuring out the precise proportion of citizens who comply with legal mandates for moral reasons that owe their existence (at least partly) to legal systems (assuming some moral reasons owe their existence at least partly to legal systems). As far as I'm aware, there is no empirical work on the topic, so it is not possible to say more than that this way legal systems influence behaviour seems to be common.

Given what I've said so far about legal systems influencing behaviour by legitimacy and by influencing people's moral landscape, it is already possible to conclude that legal systems' non-coercive influence on behaviour appears to be more prominent than Schauer (and others) had suggested - it is at least not 'so small as to be hardly worth worrying about'. ${ }^{54}$ That, of course, is still insufficient to establish that legal systems' non-coercive influence is pervasive and that legal systems' coercive influence is not (or that the coercive and non-coercive influence are on par, which would also be enough to refute (Compliance*)). There are, however, additional considerations that lend more plausibility to the view that legal systems' non-coercive influence is prominent.

\subsection{Expressive Powers and the Role of Expectations}

A considerable body of evidence has shown that people's compliance with rules-legal and otherwise - is strongly affected by both empirical and normative expectations. ${ }^{55}$ Frequently, an agent is more inclined to comply with a given rule when and because she believes that others in her group or society are complying (i.e. when she has an empirical expectation). And an agent is also frequently more inclined to comply with a given rule when and because she believes that others in her group or society believe that

\footnotetext{
${ }^{53}$ Ibid., p. 365.

${ }^{54}$ Schauer (2015), p. 46; Plaxton (2012).

${ }^{55}$ Cristina Bicchieri, for example, has carried out a number of empirical studies on the topic and provided an extensive and helpful discussion on it in a series of works on the topic. See, e.g., Bicchieri (2006); Bicchieri and Xiao (2008); Bicchieri and Chavez (2010).
} 
she ought to comply with the rule (i.e. when she has a normative expectation). This influence of expectations in rule-compliance occurs both in the absence of the threat of unwelcome consequences and in the absence of people taking the rules as legitimate. ${ }^{56}$

There is evidence that legal systems can and, to a significant extent, do influence behaviour by creating expectations. A growing body of literature is dedicated to show that legal systems possess and utilise what is known as 'expressive powers'. ${ }^{57}$ Two distinct expressive powers are taken to influence citizens' compliance with the law: the power to coordinate (i.e., the power to solve coordination problems) and the power to convey information. These powers are said to be 'expressive' because they are abilities to influence behaviour by the mere expression of rules, directives or guidelines. $^{58}$

To see how legal systems' use of these powers are related to what I've said about expectations, consider simple (or 'pure', as it is often called) coordination problems; problems where those involved have no preference for a particular solution but still prefer to adopt the solution favoured by most. Some traffic problems provide an example. Most people prefer to drive on the same side as other people and have no preference for a particular side. ${ }^{59}$ Figuring out what side most people are likely to drive in the absence of certain rules or conventions may be difficult. Legal systems change that. By passing a law requiring citizens to drive on the right side, legal systems solve the coordination problem. And they solve the problem by creating a 'coordination focal point'; ${ }^{60}$ i.e., by making a given solution to the problem salient to the point that the advantages associated with adopting the solution create an expectation that most will adopt it. ${ }^{61}$

The point is that, in certain contexts-like in the traffic example-the mere expression of a law makes a given solution to a coordinative problem salient and leads people to believe that others are likely to adopt it. Because many don't want to be viewed as outliers and prefer to do what others will likely do in this type of situation, citizens comply with the behaviour required by legal systems without taking sanctions and unwelcome consequences into account, or without evaluating the legitimacy of what is required by law. ${ }^{62}$

There is reason to think that simple coordination problems are widespread and so are the cases where legal systems influence behaviour by simply making a solution to these coordination problems salient and by creating expectations. ${ }^{63}$ Traffic laws are not

\footnotetext{
${ }^{56}$ Gerald Gaus elaborates on some implications of this feature of Bicchieri's work to discussions in political philosophy. See Gaus (2016), p. 5.

${ }^{57}$ See McAdams (2000); McAdams and Nadler (2005); McAdams and Nadler (2008); McAdams (2015).

${ }^{58}$ McAdams (2015), p. 5.

59 Of course, people who are accustomed to driving on a particular side of the road may have a strong preference for that side. My point presupposes a scenario where driving rules have been first introduced to a population new to driving. The central point being made in the passage, however, works for any kind of pure coordination problem. So, if the reader finds the driving example too unrealistic, I suggest them to adapt the example.

${ }^{60}$ McAdams (2015), p. 57 and passim.

${ }^{61}$ Ibid., pp. $42-43$ and passim.

${ }^{62}$ Nadler (2017), pp. 64-65.

${ }^{63}$ A helpful and detailed case for this claim is made by Richard McAdams. See McAdams (2015), pp. 27-42.
} 
the only examples. Many laws that provide (binding and non-binding) guidelines to traders, health providers, bankers, constructors, advertisers, manufacturers, and policymakers; laws that set standards (e.g., laws that define what counts as legal tender, laws that set common communication protocols for international and domestic air-traffic control, laws that set standards for the operation of electrical grids, etc); as well as a considerable bulk of administrative law and by-laws fall into this category. ${ }^{64}$

Even more widespread, however, is the presence of complex coordination problems; problems where everyone involved would be better-off by adopting the same solution but where different solutions are preferred - sometimes even strongly-by those involved. ${ }^{65}$ An example is agreeing on how often a democracy should have elections. Citizens in a democracy may each have strong and conflicting preferences about the matter. But they will be better-off by agreeing on a common number than by insisting on their own preferences and failing to solve the problem.

Legal systems also influence behaviour independently from the threat of unwelcome consequences while providing solutions to complex coordination problems. The way legal systems influence behaviour in these scenarios is similar, but not identical, to the way they do while providing solutions to simple coordination problems. Examples are legion, they range from provisions in constitutional and in international law that are not backed by the threat of sanctions, to common contractual provisions in private law. To name a few: determining the minimum and maximum age for someone to occupy the presidential office, or the number of votes necessary for a constitutional amendment, or the terms and form of trade agreements, the margin of negotiation in employment contracts, etc. ${ }^{66}$

As interesting as these findings are and as numerous as the examples where legal systems influence behaviour independently from the threat of unwelcome consequences may seem to be, we should not be hasty and assume that law's noncoercive side is what mostly influences citizens' behaviour.

First, and as I have highlighted in the first section, knowledge of legal mandates is generally poor among citizens. And this impacts the non-coercive influence of the law just as equally as it impacts the law's coercive influence. As Richard MacAdams puts it:

Not knowing a particular law exists, [citizens] will not fear legal sanctions for violating it, not defer to its legitimacy, not use it to solve a coordination problem, and (...) not update beliefs in light of the information the law reveals. ${ }^{67}$

Second, some of the studies are based on surveys and are not considered robust by some social scientists. ${ }^{68}$ Third, there are certain studies that seem to favour the view that legal mandates only rarely influence behaviour by means other than the threat of unwelcome consequences. Schauer has cited a few in support of his thesis, though he has also

\footnotetext{
${ }^{64}$ For examples in administrative law and by-laws see Nadler (2017), p. 66.

${ }^{65}$ McAdams (2015), chap. 2.

${ }^{66}$ For more examples, see Ibid., pp. 67-92; Nadler (2017).

${ }^{67}$ McAdams (2015), p. 137.

${ }^{68}$ Nadler (2017), p. 63.
} 
acknowledged that they have serious limitations. ${ }^{69}$ Finally, and more fundamentally, the empirical studies to date face significant methodological challenges. It is hard to effectively isolate the factors that influence citizens' behaviour. And, as it appears to be the case, the empirical studies to date - regardless of the conclusion they support - are yet to overcome these methodological challenges. ${ }^{70}$

To find out the extent to which the influence of legal mandates on behaviour is due to the threat of unwelcome consequences and the extent to which the influence is due to other factors we need to wait for more and better empirical evidence. While we wait for more and better evidence, the acceptable attitude is to suspend judgement. As of now, we just cannot determine with enough confidence if (Compliance*) is true or not.

But what if new and more robust empirical studies emerge and show that (Compliance*) holds after all?

This would be an interesting conclusion, but its impact would be far less significant than one might think. Even if it turns out that coercion accounts for most cases where legal systems influence citizens' behaviour, we should not forget what we've concluded in the first section of this paper: that most people most of the time are not influenced by legal mandates. They comply with legal mandates for reasons which are independent from law's influence.

This doesn't happen by accident. Citizens often tend to favour prosocial behaviour and are influenced by their social, cultural, and moral norms and beliefs. Insofar as many social, cultural, and moral norms and beliefs are not harmful to society, the most obvious choice for legal authorities is to issue legal mandates that, as far as possible, match or strengthen citizens' pre-existing norms and beliefs. On top of that, legal authorities understand that coercion is extremely costly. Given the practical difficulties associated with coercing citizens, motivating citizens via the threat of unwelcome consequences is often intentionally left as a last resort. The increase of legal systems' reliance on alternative regulatory mechanisms — such as nudging — can attest to that. $^{71}$

More fundamentally, on some occasions the threat of sanctions and unwelcome consequences can either backfire or have no effect in motivating citizens to comply with legal mandates. This makes us wonder why legal systems succeed in motivating citizens via the threat of unwelcome consequences in some circumstances and fail in others.

As recent empirical studies show, unless the threat of sanctions and unwelcome consequences are legitimated by underlying cultural, social and moral norms and

\footnotetext{
${ }^{69}$ Schauer (2015), pp. 64-65; Schauer (2017), p. 93.

${ }^{70}$ See Schauer (2015), p. 64; Schauer (2017), p. 92. See also McAdams (2015), p. 8.

${ }^{71}$ For a helpful, and somewhat historical, overview of the shift from regulation centred on negative incentives to alternative and more nuanced forms of motivating compliance with legal mandates, see Lessig (1998). The growth of alternative regulation such as nudging is not an unknown phenomenon; it has even made it to the news. For a news piece focused on the UK, see Rutter T (2015) The rise of nudge - the unit helping politicians to fathom human behaviour. In: The Guardian. https://www.theguardian.com/public-leaders-network/2015/jul/23/rise-nudge-unit-politicians-humanbehaviour. Accessed 15 November 2017.
} 
beliefs, they are likely to fail in influencing behaviour. To put this in a different way: available evidence suggests that the influence of the threat of unwelcome consequences is parasitic on the fact that they are supported by underlying cultural, social, and moral norms and beliefs. ${ }^{72}$

Schauer and others may end up being right about (Compliance*). But even if right, they have missed something important: that even if very often present, the influence of the threat of legal sanctions and other unwelcome consequences is still of secondary importance to our legal systems. Whatever role they play in affecting citizens' behaviour is conditioned upon the sanctions being supported by underlying social, cultural, and moral norms and beliefs.

\section{Conclusion}

H.L.A Hart once said that coercion has an ancillary role in legal systems. What he meant was that sanctions and unwelcome consequences were applied only when all else fails. ${ }^{73}$ Given what we now know from empirical studies, we can go further than Hart and ascribe an even more exceptional and ancillary role to coercion. It is not just that coercive mechanisms motivate citizens in exceptional circumstances. When they do succeed in motivating citizens, their success tends to be due to the support of underlying social norms and the fact that citizens accept them as legitimate.

Hobbes' famous adage - 'Covenants without swords are but words' - has played an enormous influence in legal and political philosophy as well as in our common understanding of our legal systems and the state. What we now know shows that it is time to reverse the adage and accord coercion a less prominent place in our thought and talk about typical legal systems: Swords without legitimate covenants are but cold blades.

\section{References:}

Abbink K, Gangadharan L, Handfield T, Thrasher J (2017) Peer Punishment Promotes Enforcement of Bad Social Norms. Nature Communications 8:609 . doi: $10.1038 / \mathrm{s} 41467-017-00731-0$

Anderson E (2000) Beyond Homo Economicus: New Developments in Theories of Social Norms. Philosophy \& Public Affairs 29:170-200 . doi: 10.1111/j.10884963.2000.00170.x

Aquinas T (1947) Summa Theologica (A Treatise in Theology). Benziger Bros, New York

\footnotetext{
72 Bicchieri et al. (2017). See also references therein. Gerald Gaus has made a similar point and explored these conclusions to political philosophy. See Gaus (2016). Gaus also mentioned this point in a recent interview. See Marshall R, Gaus G (2016) The Tyranny of the Ideal. In: 3:AM Magazine. http://www.3ammagazine.com/3am/the-tyranny-of-the-ideal/. Accessed 15 November 2017. In a similar vein, Richard McAdams argues for another sense in which the threat of unwelcome consequences is parasitic on legal system's non-coercive side. He defends that legal sanctions 'owe their power entirely to the law's ability to facilitate coordination expressively'. McAdams (2015), p. 7 and 57-67.

${ }^{73}$ Hart (2012), pp. 21, 39.
} 
Batson CD, Shaw LL (1991) Evidence for Altruism: Toward a Pluralism of Prosocial Motives. Psychological Inquiry 2:107-122 . doi: 10.1207/s15327965pli0202_1

Bicchieri C (2006) The Grammar of Society: The Nature and Dynamics of Social Norms. Cambridge University Press, Cambridge

Bicchieri C, Chavez A (2010) Behaving as expected: Public information and fairness norms. J Behav Decis Making 23:161-178 . doi: 10.1002/bdm.648

Bicchieri C, Dimant E, Xiao E (2017) Deviant or Wrong? The Effects of Norm Information on the Efficacy of Punishment. CeDex Discussion Paper Series

Bicchieri C, Xiao E (2008) Do the right thing: But only if others do so. Journal of Behavioral Decision Making 22:191-208 . doi: 10.1002/bdm.621

Bowles S, Gintis H (2011) A Cooperative Species: Human Reciprocity and Its Evolution. Princeton University Press, Princeton

Brennan J (2017) Private Governance and The Three Biases of Political Philosophy. Rev Austrian Econ 1-9 . doi: 10.1007/s11138-017-0384-1

Burazin L (2019) The Concept of Law and Efficacy. In: Sellers M, Kirste S (eds) Encyclopedia of Philosophy of Law and Social Philosophy. Springer

Burton-Chellew MN, Mouden CE, West SA (2017) Evidence for Strategic Cooperation in Humans. Procedings of the Royal Society B 284:20170689 . doi: 10.1098/rspb.2017.0689

Darley JM, Carlsmith KM, Robinson PH (2001) The Ex Ante Function of the Criminal Law. Law \& Society Review 35:165-190 . doi: 10.2307/3185389

Darley JM, Sanderson C, LaMantia PS (1996) Community Standards for Defining Attempt: Inconsistencies With the Model Penal Code. American Behavioral Scientist 39:405-420 . doi: $10.1177 / 0002764296039004005$

Dawes RM, Van de Kragt AJ, Orbell JM (1990) Cooperation For the Benefit of Us-Not me, or My Conscience. In: Mansbridge J (ed) Beyond Self-Interest. University of Chicago Press, Chicago, pp 97-110

Ellickson RC (1991) Order without Law: How Neighbors Settle Disputes. Harvard University Press

Ellickson RC (2017) Forceful Self-Help and Private Voice: How Schauer and McAdams Exaggerate a State's Ability to Monopolize Violence and Expression. Law and Social Inquiry 42:49-59 . doi: 10.1111/1si.12268

Embrey M, Fréchette GR, Yuksel S (Forthcoming) Cooperation in the Finitely Repeated Prisoner's Dilemma. Q J Econ. doi: 10.1093/qje/qjx033

Fehr E, Rockenbach B (2003) Detrimental Effects of Sanctions on Human Altruism. Nature 422:137-140 . doi: 10.1038/nature01474

Finnis J (2011) Natural Law and Natural Rights, 2nd edn. Oxford University Press, Oxford 
Frey BS, Oberholzer-Gee F (1997) The Cost of Price Incentives: An Empirical Analysis of Motivation Crowding- Out. The American Economic Review 87:746-755

Gaus G (2016) The open society as a rule-based order. Erasmus Journal for Philosophy and Economics 9:1-13

Gibson JL, Caldeira GA, Spence LK (2005) Why Do People Accept Public Policies They Oppose? Testing Legitimacy Theory with a Survey-Based Experiment. Political Research Quarterly 58:187-201 . doi: 10.1177/106591290505800201

Gneezy U, Rustichini A (2000) A Fine Is a Price. The Journal of Legal Studies 29:1-17 . doi: $10.1086 / 468061$

Greenberg M (2018) How Law Affects Behaviour. Jurisprudence 9:374-384 . doi: $10.1080 / 20403313.2017 .1333256$

Hart HLA (2012) The Concept of Law, 3rd edn. Oxford University Press, Oxford

Heyman J, Ariely D (2004) Effort for payment. A tale of two markets. Psychological Science 15:787-793 . doi: 10.1111/j.0956-7976.2004.00757.x

Himma KE (2016) The Authorisation of Coercive Enforcement Mechanisms as a Conceptually Necessary Feature of Law. Jurisprudence 7:593-626

Huang BI (2017) Law and Moral Dilemmas (Book Review). Harvard Law Review 130:659-700

Hughes RC (2018) Would many people obey non-coercive law? Jurisprudence 9:361-367 . doi: $10.1080 / 20403313.2017 .1333257$

Jones MM, Bayer R (2007) Paternalism \& Its Discontents: Motorcycle Helmet Laws, Libertarian Values, and Public Health. American Journal of Public Health 97:208-217 . doi: 10.2105/AJPH.2005.083204

Kim PT (1997) Bargaining with Imperfect Information: A Study of Worker Perceptions of Legal Protection in an At-Will World. Cornell L Rev 83:105-160

Lamond G (2001) Coercion and the Nature of Law. Legal Theory 7:35-57

Lessig L (1998) The New Chicago School. The Journal of Legal Studies 27:661-691 . doi: $10.1086 / 468039$

McAdams RH (2000) A Focal Point Theory of Expressive Law. Virginia Law Review 86:16491729 . doi: $10.2307 / 1073827$

McAdams RH (2015) The expressive powers of law: Theories and limits. Harvard University Press, Cambridge

McAdams RH, Nadler J (2005) Testing the Focal Point Theory of Legal Compliance: The Effect of Third-Party Expression in an Experimental Hawk/Dove Game. Journal of Empirical Legal Studies 2:87-123 . doi: 10.1111/j.1740-1461.2005.00032.x

McAdams RH, Nadler J (2008) Coordinating in the Shadow of the Law: Two Contextualized Tests of the Focal Point Theory of Legal Compliance. Law \& Society Review 42:865898 . doi: $10.1111 / \mathrm{j} .1540-5893.2008 .00361 . x$ 
Miotto L (2016) Evaluating the Force of Law's Force. Australian Journal of Legal Philosophy 40:229-236

Mullen E, Nadler J (2008) Moral spillovers: The Effect of Moral violations on Deviant Behavior. Journal of Experimental Social Psychology 44:1239-1245 . doi: 10.1016/j.jesp.2008.04.001

Nadler J (2004) Flouting the Law. Tex L Rev 83:1399-1442

Nadler J (2017) Expressive Law, Social Norms, and Social Groups. Law and Social Inquiry 42:60-75 . doi: 10.1111/1si.12279

Ostrom E (1990) Governing the Commons: The Evolution of Institutions for Collective Action. Cambridge University Press, New York

Papachristos AV, Meares TL, Fagan J (2012) Why do Criminals Obey The Law? The Influence of Legitimacy and Social Networks on Active Gun Offenders. The Journal of Criminal Law and Criminology (1973-) 102:397-440

Paternoster R (2010) How Much Do We Really Know About Criminal Deterrence? Journal of Criminal Law and Criminology 100:765-823

Plaxton M (2012) The Challenge of the Bad Man. McGill L J 58:451-482

Robinson PH, Darley JM (2004) Does Criminal Law Deter? A Behavioural Science Investigation. Oxf J Leg Stud 24:173-205 . doi: 10.1093/ojls/24.2.173

Robinson PH, Goodwin GP, Reisig MD (2010) The Disutility of Injustice. New York University Law Review 85:1940-2033

Ross D (2012) The Economic Agent: Not Human, But Important. In: Mäki U (ed) Philosophy of Economics, 1st edn. Elsevier, North Holland, pp 627-671

Schauer F (2015) The Force of Law. Harvard University Press, Cambridge

Schauer F (2017) Preferences for Law? Law and Social Inquiry 42:87-99 . doi: $10.1111 / 1$ si.12281

Sherman L (1993) Defiance, Deterrence, and Irrelevance: A Theory of the Criminal Sanction. Journal of Research in Crime and Delinquency 30:445-473 . doi: $10.1177 / 0022427893030004006$

Spinoza B (2007) Theological-Political Treatise. Cambridge University Press

Stringham EP (2015) Private Governance: Creating Order in Economic and Social Life. Oxford University Press, New York

Thaler RH (2000) From homo economicus to homo sapiens. The Journal of Economic Perspectives 14:133-141

Tyler TR (2006a) Why People Obey the Law. Princeton University Press, Princeton

Tyler TR (2006b) Psychological perspectives on legitimacy and legitimation. Annual Review of Psychology 57:375-400 . doi: 10.1146/annurev.psych.57.102904.190038 
Penultimate Draft - Forthcoming in Jorge Fabra-Zamora and Gonzalo Villa Rosas, Conceptual Jurisprudence: Methodological Issues, Conceptual Tools, and New Approaches. Springer.

Tyler TR, Jackson J (2014) Popular legitimacy and the exercise of legal authority: Motivating compliance, cooperation, and engagement. Psychology, public policy, and law 20:78

Weber M (1978) Economy and Society: An Outline of Interpretive Sociology. University of California Press, Berkeley, CA 